\title{
The Impact of COVID-19 Pandemic on Blood Transfusion Services: A Perspective from Health Professionals and Donors
}

\author{
Elhadi Miskeen (D) \\ Amar Ibrahim Omer Yahia (iD ${ }^{2}$ \\ Tarig Babikir Eljack ${ }^{2}$ \\ Hatim Khalifa Karar ${ }^{3}$ \\ 'Department of Obstetrics and \\ Gynaecology, College of Medicine, \\ University of Bisha, Bisha, 61922, Saudi \\ Arabia; ${ }^{2}$ Unit of Pathology Department of \\ Basic Medical Sciences, College of \\ Medicine, University of Bisha, Bisha, \\ 61922, Saudi Arabia; ${ }^{3}$ Department of \\ Pathology and Laboratory Medicine, King \\ Abdullah Hospital, Bisha, Saudi Arabia
}

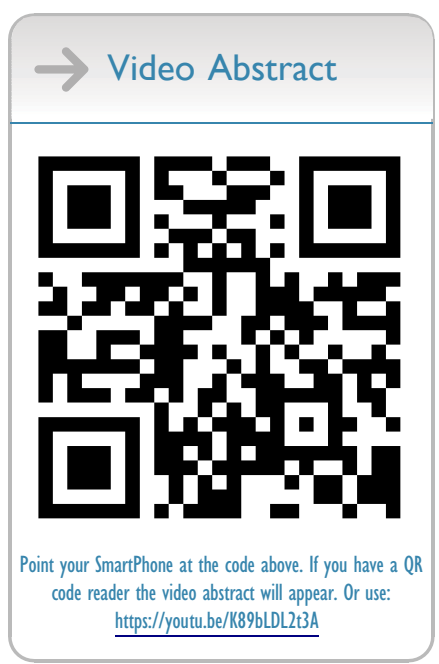

Correspondence: Elhadi Miskeen Department of Obstetrics and Gynaecology, College of Medicine, University of Bisha, P.O. Box 1290, Bisha, 61922, Saudi Arabia

Email emiskeen@ub.edu.sa
Purpose: Since the emergence of the COVI9-19 pandemic, there has been concern about the availability and sufficiency of blood transfusions to meet patient needs. Also, the adequate and safe blood supply is a major issue to fulfill present demands. This study aims to determine the impact of the COVID-19 pandemic on the blood transfusion service and identify solutions to overcome this impact from the perspective of blood donors and healthcare professionals.

Methods: This study was conducted prospectively among Saudi Arabian blood donors and healthcare professionals between May 2020 and May 2021. A group of professional health care professionals and blood donors participated in this study to determine the impact of the COVID-19 pandemic on blood transfusion services and identify possible solutions to overcome the adverse effects on blood system activities.

Results: To understand the impact of pandemic COVID-19 on blood transfusion services in Saudi Arabia, we investigated population dynamics and statistical analysis from different age groups and health care professionals. A total of 424 blood donors and 372 healthcare professionals participated in this study. The suggested solution by the participants to overcome the blood shortage during pandemics was the organization of mobile blood drives at donors' homes, work, and educational sites. Statically significant associations were found between blood donation during this pandemic and age $(p=0.019)$ and marital status $(p=0.001)$.

Conclusion: The findings of this study highlight the main problems of blood transfusion due to the onset of COVID-19. Hence, the data could be a source of improving blood transfusion and blood donation systems by healthcare centers and on an individual basis. Healthcare professionals use this public management system in hospitals to minimize the adverse effects of the pandemic.

Keywords: health-care professionals, blood transfusion, blood donation, COVID-19

\section{Introduction}

Blood transfusions are an indispensable part of health care in all medical disciplines. With the advent of the pandemic COVID-19, the adequate and safe availability of blood to meet patient needs became a significant concern. There is a widespread shortage of blood supply and demand in many parts of the world, significantly affecting blood transfusion services. ${ }^{1-7}$

The blood donation process was negatively influenced by the COVID-19 pandemic due to a dramatic decrease in blood donors, forcing blood banks and blood donation centers to implement new policies to increase blood supply while protecting donors from COVID-19 infection. ${ }^{8}$ 


\section{Outbreaks of COVID-19 Lower Blood Supply}

The responsibility of the blood bank includes recruiting donors and testing the donated blood. Therefore, direct donation is the main source of blood. ${ }^{9}$ World Health Organization reported coronavirus diseases as a pandemic when uncountable people around the globe were dying from this infection. Many countries had imposed a lockdown to control the outbreaks of the coronavirus. ${ }^{3,10}$

Although blood transfusions are considered an indispensable part of health care providers in all medical disciplines, a wave of panic was created on social media and among common people who directly affected the blood donation system. The fear of getting infected with COVID-19 while transfusing blood becomes of great concern. A really hard time was faced by blood transfusion centers during the pandemic COVID-19 in many parts of the world, thus generating a shortage of blood services and blood donors. The ratio of blood donation significantly decreased by $40 \%$ to $67 \%$, especially during COVID- 19 worldwide. Active donors failed to approach blood transfusion centers, and people are dying with other diseases and pandemic COVID-19 due to a shortage of blood supply. ${ }^{11,12}$ On average, more than 118.5 million blood units are collected worldwide. ${ }^{13}$ It is estimated that the blood donation rate is three folds higher in developed countries than in underdeveloped countries. An adequate amount of blood supply can be provided in donations by the designated blood transfusion centers, mostly via volunteer donors and sometimes via paid donors when there is an urgent need for blood supply, as we can observe during disasters and pandemic situation of COVID-19. ${ }^{14,15}$

Not only pandemic COVID-19 is a cause behind low blood supply but the emergence of potent viruses and deadly diseases, ie, HIV, hepatitis B, C, cancer, liver cirrhosis, and bleeding disorders (Thalassemia and Hemophilia), were also responsible for creating blood shortages. It has been reported that $13.4 \%$ infected with coronavirus required blood transfusion compared with non-COVID-19 patients. Also, special care should be considered while handling infected patients' blood samples (13 blood transfusion services). A recent report published by the World Health Organization (WHO) estimated that the pandemic COVID-19 decreased $20 \%$ to $30 \%$ blood donors in many countries. However, in the early phases of COVID-19, there was only an incidence of reduction in blood supply. ${ }^{16}$

\section{How to Increase Blood Supply in Blood Banks?}

To overcome the disruptive situation of blood supply, blood donation centers are thinking of implementing new policies to increase blood demand and particular concern to protect donors from COVID-19 infection. ${ }^{7}$ Phone calls, SMS, and email can be an excellent strategy to access donors, along with free blood screening that might increase the ratio of donors. Blood screening not only fulfills blood supply for COVID-19 patients but also identifies infected people. However, other options such as mobile blood drives are also activated in case of a blood shortage. Moreover, health care organizations should issue emergency calls to the people of the nation for blood donation. It is crucial in the modern era to supply adequate blood to fight novel diseases. Mortality rates have been increasing by a decreased blood supply in many countries. Even in a critical situation where surgery is required in the hospitals, surgeons might hold the procedures. The disruptive situation of blood supply blood donation centers is implementing new policies to increase blood demand and particular concern to protect donors from COVID-19 infection. $^{8}$

In Saudi Arabia, the blood transfusion service is a hospitalbased blood bank. However, other options such as mobile blood drives are also activated in case of a blood shortage. This study aims to determine the impact of the COVID-19 pandemic on the blood transfusion services, mainly in Saudi Arabia, and identify solutions to overcome this impact from the perspective of blood donors and healthcare professionals. Thus far, more efforts are required to mitigate the shortage of blood supply caused by pandemic COVID-19.

\section{Methodology \\ Study Design}

This study was conducted prospectively among blood donors and healthcare professionals in Saudi Arabia between May 2020 and May 2021.

\section{Study Population}

The study involved two population groups. The first group included blood donors. Individuals who were less than 18 years of age and not donated before were excluded from the study. The second group included healthcare professionals. All participants, regardless of gender, nationality, educational level, or specialty, were enrolled. 
Table I Sociodemographic and General Characteristics of Blood Donor's Participants ( $n=424)$

\begin{tabular}{|c|c|c|c|c|c|}
\hline \multicolumn{2}{|c|}{ Sociodemographic Data and General Characteristics } & \multicolumn{2}{|c|}{ Donation During the COVID-I9 Pandemic } & \multirow[t]{2}{*}{ Total } & \multirow[t]{2}{*}{ P-value } \\
\hline & & Yes & No & & \\
\hline Age groups (years) & $\begin{array}{l}18-28 \\
29-39 \\
40-50 \\
51-61 \\
>62\end{array}$ & $\begin{array}{l}33(7.8) \\
23(5.4) \\
18(4.2) \\
I(0.3) \\
3(0.7)\end{array}$ & $\begin{array}{l}\text { I I } 8(27.9) \\
\text { I27 (29.9) } \\
88(20.8) \\
\text { I2(2.8) } \\
\text { I }(0.2)\end{array}$ & $\begin{array}{l}151(35.7) \\
150(35.3) \\
106(25) \\
13(3.1) \\
4(0.9)\end{array}$ & 0.019 \\
\hline Residency & $\begin{array}{l}\text { Rural } \\
\text { Urban }\end{array}$ & $\begin{array}{l}25(5.9) \\
53(12.5)\end{array}$ & $\begin{array}{l}103(24.3) \\
243(57.3)\end{array}$ & $\begin{array}{l}128(30.2) \\
296(69.8)\end{array}$ & 0.39 \\
\hline Gender & $\begin{array}{l}\text { Female } \\
\text { Male }\end{array}$ & $\begin{array}{l}15(3.6) \\
63(14.8)\end{array}$ & $\begin{array}{l}90(21.2) \\
256(60.4)\end{array}$ & $\begin{array}{l}105(24.8) \\
319(75.2)\end{array}$ & 0.13 \\
\hline Educational level & $\begin{array}{l}\text { Pre-university } \\
\text { University } \\
\text { Post-graduate }\end{array}$ & $\begin{array}{l}41(9.6) \\
11(2.6) \\
26(6.2)\end{array}$ & $\begin{array}{l}225(53.1) \\
34(8) \\
87(20.5)\end{array}$ & $\begin{array}{l}266(62.7) \\
45(10.6) \\
113(26.7)\end{array}$ & 0.11 \\
\hline Occupation & $\begin{array}{l}\text { Education-sector } \\
\text { Military-sector } \\
\text { Health-sector } \\
\text { Other } \\
\text { Workless }\end{array}$ & $\begin{array}{l}17(4) \\
15(3.5) \\
19(4.5) \\
13(3.1) \\
14(1.4)\end{array}$ & $\begin{array}{l}93(21.9) \\
49(11.6) \\
70(16.5) \\
86(20.2) \\
48(13.3)\end{array}$ & $\begin{array}{l}110(25.9) \\
64(15.1) \\
89(21) \\
99(23.3) \\
62(14.7)\end{array}$ & 0.13 \\
\hline Marital status & $\begin{array}{l}\text { Single } \\
\text { Married } \\
\text { Divorced/widowed }\end{array}$ & $\begin{array}{l}38(9) \\
35(8.3) \\
5(1.2)\end{array}$ & $\begin{array}{l}124(29.2) \\
218(51.4) \\
4(0.9)\end{array}$ & $\begin{array}{l}162(38.2) \\
253(59.7) \\
9(2.1)\end{array}$ & 0.001 \\
\hline Nationality & $\begin{array}{l}\text { Saudi } \\
\text { Non-Saudi }\end{array}$ & $\begin{array}{l}77(18.1) \\
I(0.3)\end{array}$ & $\begin{array}{l}337(79.5) \\
9(2.1)\end{array}$ & $\begin{array}{l}414(97.6) \\
10(2.4)\end{array}$ & 0.42 \\
\hline Type of blood donation & $\begin{array}{l}\text { Voluntary } \\
\text { Replacement } \\
\text { Paid }\end{array}$ & $\begin{array}{l}47(4.2) \\
25(5.9) \\
6(5)\end{array}$ & $\begin{array}{l}283(66.5) \\
57(13.4) \\
6(5)\end{array}$ & $\begin{array}{l}330(70.7) \\
82(19.3) \\
12(10)\end{array}$ & 0.00 \\
\hline Easy accessibility to blood bank & $\begin{array}{l}\text { Yes } \\
\text { No }\end{array}$ & $\begin{array}{l}74(17.4) \\
4(0.9)\end{array}$ & $\begin{array}{l}287(67.7) \\
59(14)\end{array}$ & $\begin{array}{l}361(85.1) \\
63(14.9)\end{array}$ & 0.007 \\
\hline
\end{tabular}

\section{Sample Size}

The following formula was used for sample size calculation:

$\mathrm{n}=\mathrm{Z} \alpha / 22 \times \mathrm{p}(1-\mathrm{p}) / \mathrm{d} 2=(1.96) 2 \times 0.5(1-0.5) / 0.05$ $=384$

where $\mathrm{Z} \alpha / 2=1.96$ at a $95 \%$ confidence interval, $\mathrm{p}=$ $50 \%$ (as there is no previous published study in this study area), and $d=5 \%$, which is the marginal error. Based on this calculation. We enrolled 424 blood donors and 372 health care professionals.

\section{Data Collection}

Two self-administered questionnaires were used for data collection. One directed to the blood donors, which includes sociodemographic characteristics and their suggestions for the most suitable blood donation sites. The second one directed healthcare professionals to find the possible solutions to blood shortage during this pandemic.

Information collected includes the following:

- Sociodemographic and general characteristics of blood donors

- Preferable donation site, barriers and motivational factor (s), blood donation safety from the perspective of blood donors.

- General characteristics of the healthcare professionals.

- Solutions suggested by the healthcare professionals

- Implementation of the national strategy for blood management in health institutions. 


\section{Data Analysis}

The data obtained were analyzed using Statistical Package for Social Sciences (SPSS) 25.0. Categorical variables were described by frequency and percentage. The Chisquare test was used to perform cross-tabulation for comparison between the selected groups of variables. The statistical significance limit was taken as $\mathrm{p}=0.05$.

\section{Results}

In this study, we enrolled 424 blood donors and 372 healthcare professionals. During the current COVID-19 pandemic, a decrease in blood donation frequency was observed among blood donors in the last 6 months in Saudi Arabia.

Only 179/424 (42.2\%) donated during the current COVID-19 pandemic although approximately two-thirds of regular donors were willing to donate blood during the COVID-19 pandemic 304/424 (71.7\%). Statistically significant associations were found between blood donation during the pandemic and blood donors age $(\mathrm{p}=0.019)$, marital status $(\mathrm{p}=0.001)$, voluntary blood donation $(p=0.00)$, and ease of access to the blood bank $(\mathrm{p}=0.007)$, (Table 1). One hundred and fifty-four (41.4\%) healthcare professionals experienced blood shortage during COVID-19 pandemic. Blood shortage was due to shortage of blood donors 300/372 (80.6\%) due to donors' fear of exposure to SARS-CoV-2 at a blood donation site 278/424 (65.6\%). Very few motivate for payment, however. In Saudi Arabia, blood donor payment is not allowed and forbidden by law (Table 2). The main factor behind the blood shortage was the smaller number of donors, ie, 300/372 (80.6\%) and phobia of exposure to SARS-CoV-2 at blood donation site, ie, 278/424 (65.6\%). To overcome this problem participant of this study were suggested to provide mobile blood drives. A total of $353(83.3 \%)$ and $282(75.8 \%)$ blood samples were collected after launching of blood mobile drives (Table 3).

Regarding the safety of blood donations from the donors' point of view, $105(24.7 \%)$ believe that it is an infection, $136(32 \%)$ stated that there is a high risk of transmission of infection when donating blood in the bank, and $292(68.9 \%)$ stated that blood donations are essential during the pandemic COVID-19 and in such emergencies (Figure 1).

A total of 372 healthcare professionals and 424 blood donors were enrolled to conduct this study. Significant
Table 2 Blood Donation's Barriers and Motivational Factor(s); Perspective of the Participants $(n=424)$

\begin{tabular}{|l|l|}
\hline $\begin{array}{l}\text { What is/are the barrier(s) to blood donation } \\
\text { during the COVID-19 pandemic? }\end{array}$ & Number (\%) \\
\hline $\begin{array}{l}\text { Fear from the infection } \\
\text { Lockdown }\end{array}$ & $278(65.6)$ \\
The blood bank is not easily accessible & $54(12.7)$ \\
Other & $50(11.8)$ \\
TOTAL & $42(9.9)$ \\
\hline What is the main motivational factor to blood donation \\
during the COVID-19 pandemic? & $424(100)$ \\
\hline Relatives in need & $220(5 I .9)$ \\
Humanity duty & $118(27.8)$ \\
Religious duty & $27(6.4)$ \\
Nationality duty & $22(5.2)$ \\
Looking for money (In KSA, blood donor payment & $9(2.1)$ \\
is not allowed and forbidden by law) & \\
Other & $28(6.6)$ \\
TOTAL & $424(100)$ \\
\hline
\end{tabular}

Table 3 Blood Donation in COVID-19 Time; Response of the Participants $(n=424)$

\begin{tabular}{|c|c|c|}
\hline \multirow{2}{*}{\multicolumn{2}{|c|}{$\begin{array}{l}\text { Blood Donation During the COVID-19 } \\
\text { Pandemic }\end{array}$}} & \multirow{3}{*}{$\begin{array}{c}\text { Response } \\
\text { Number (\%) } \\
304 \text { (71.7) } \\
120(28.3)\end{array}$} \\
\hline & & \\
\hline $\begin{array}{l}\text { In COVID-19 time, are you willing to } \\
\text { donate blood? }\end{array}$ & $\begin{array}{l}\text { Yes } \\
\text { No }\end{array}$ & \\
\hline $\begin{array}{l}\text { Have you ever donated blood in } \\
\text { current COVID-19 pandemic? }\end{array}$ & $\begin{array}{l}\text { Yes } \\
\text { No }\end{array}$ & $\begin{array}{l}179(42.2) \\
245(57.8)\end{array}$ \\
\hline Where did you donated? & $\begin{array}{l}\text { Blood bank } \\
\text { Mobile } \\
\text { blood } \\
\text { drives }\end{array}$ & $\begin{array}{l}118(65.6) \\
61(34.1)\end{array}$ \\
\hline $\begin{array}{l}\text { Have you known of your relative or } \\
\text { friend in need for blood during this } \\
\text { pandemic? }\end{array}$ & $\begin{array}{l}\text { Yes. } \\
\text { No. }\end{array}$ & $\begin{array}{l}104(24.5) \\
320(75.5)\end{array}$ \\
\hline $\begin{array}{l}\text { During this pandemic, did you } \\
\text { receive a request for urgent blood } \\
\text { donation? }\end{array}$ & $\begin{array}{l}\text { Yes. } \\
\text { No. }\end{array}$ & $\begin{array}{l}\mid 76(4 \mid .5) \\
248(58.5)\end{array}$ \\
\hline $\begin{array}{l}\text { In your opinion; what is the most } \\
\text { preferable donation site in case of } \\
\text { pandemics such as COVID-19? }\end{array}$ & $\begin{array}{l}\text { Mobile } \\
\text { donation } \\
\text { drives } \\
\text { Blood bank }\end{array}$ & $71(16.7 \%)$ \\
\hline
\end{tabular}

data were collected from the survey of last 6 months with the declining frequency of blood donation during pandemic situation of COVID-19 in targeted areas in Saudi Arabia (Table 4). 
Table 4 General Characteristics of the Healthcare Professional $(n=372)$

\begin{tabular}{|c|c|c|}
\hline \multicolumn{2}{|c|}{$\begin{array}{l}\text { General Characteristics of the Healthcare } \\
\text { Professionals }\end{array}$} & \multirow{3}{*}{$\begin{array}{c}\text { Number (\%) } \\
44(11.8) \\
328(88.2)\end{array}$} \\
\hline Age (years) & $<30$ & \\
\hline & $>30$ & \\
\hline \multirow[t]{2}{*}{ Gender } & Female & $86(23.1)$ \\
\hline & Male & $286(76.9)$ \\
\hline \multirow[t]{2}{*}{ Nationality } & Saudi & $204(54.8)$ \\
\hline & Non-Saudi & $168(45.2)$ \\
\hline \multirow[t]{11}{*}{ Profession } & Medicine & $90(24.2)$ \\
\hline & Surgery & $74(19.8)$ \\
\hline & Obstetricians and gynecologist & $62(16.7)$ \\
\hline & $\begin{array}{l}\text { Hematopathologists (blood bank } \\
\text { specialist) }\end{array}$ & $36(9.7)$ \\
\hline & Family medicine & $36(9.7)$ \\
\hline & Pediatric & $28(7.5)$ \\
\hline & General practitioner & $16(4.3)$ \\
\hline & Medical bioscientist & $10(2.7)$ \\
\hline & Clinical hematology & $8(2.2)$ \\
\hline & Anesthesia & $6(1.6)$ \\
\hline & ER & $6(1.6)$ \\
\hline \multirow{2}{*}{$\begin{array}{l}\text { Years of } \\
\text { experience }\end{array}$} & $<10$ & $202(54.3)$ \\
\hline & $>10$ & $170(45.7)$ \\
\hline \multirow[t]{2}{*}{ Place of work } & Rural & $86(23.1)$ \\
\hline & Urban & $286(76.9)$ \\
\hline \multirow{4}{*}{$\begin{array}{l}\text { Level of } \\
\text { hospital }\end{array}$} & Tertiary hospital & $226(60.7)$ \\
\hline & Specialize hospital & $102(27.4)$ \\
\hline & Private hospital & $20(5.4)$ \\
\hline & Other (specify) & $24(6.5)$ \\
\hline
\end{tabular}

Approximately (71.7\%) 304/424 active donors were willing to donate blood in the current pandemic situation, however only (42.2\%) 179/424 blood donated from selected donors. Hence, significant associations were found statically between blood donation and ages of blood donors during pandemic $(\mathrm{p}=0.007)$, voluntary blood donation $(\mathrm{p}=0.00)$ and easy access to the blood bank ( $\mathrm{p}=0.007)$. Simultaneously, $154(41.4 \%)$ healthcare professionals experienced shortage of blood during COVID-19.

The most common solution suggested by blood donors and healthcare professionals to overcome blood shortage was to organize mobile blood drives, $353(83.3 \%)$ and 282 (75.8\%), respectively (Table 5).

Regarding the development and implementation of the national strategy for blood supply and demand, approximately one-third of the participants 110/372 (29.6\%) reported that the strategy was developed before the emergence of the COVID-19 pandemic. However, 78//372 (21\%) reported that the strategy is not yet set in their hospitals. Moreover, $60 / 372$ (16.1\%) of the participants stated that the strategy was developed after the emergence of the COVID-19 pandemic while 124/372 (33.3\%) of the participants reported that they were unsure about the presence of the strategy (Figure 2).

\section{Discussion}

The need for blood transfusion is high in Saudi Arabia due to medical care and increased road traffic accidents. Blood donation is the backbone of blood supply worldwide as the blood is not synthesized. In emergencies such as the current COVID-19 pandemic, blood donation, and management of the blood supply is challenging and fraught with obstacles for the health system. The challenges of maintaining blood in Saudi Arabia were well highlighted in a comprehensive situation analysis. ${ }^{9}$ With the onset of the COVID-19 pandemic, concerns grew about the availability of sufficient and safe blood to meet patient needs.

Analysis of participant's surveys on blood donation is important to understand the barriers and motivational factors for blood donation. In the present study, $18.4 \%$ of the participants donated blood during the pandemic COVID19. The regular donors in Saudi Arabia reported a reduction in the frequency of their participation in blood before the COVID-19 pandemic. The current health situation is influenced in many parts of the world, including Saudi Arabia. ${ }^{17-19}$

The reduction in blood donation was explained by lockdown and fear of infection. This study indicated that the main donation barrier was the fear of infection (65.6\%), while the main motivating factor for blood donation was the presence of a needy person (51.9\%). More recent studies yielded results on barriers and motivations during the current emergency and consistent with the present findings. ${ }^{18-20}$

This is explained by fear of infection, despite that the SARS-CoV transmission by blood has not documented. ${ }^{17,21}$ However, precautions should be taken to eliminate any possibility of transmission. In the present study, more than two-thirds $(68.9 \%)$ of the participants highlighted the importance of donation in COVID-19 time, which is consistent with a recent report from many parts of the world. ${ }^{22-25}$ This positive perspective will be supportive of any donor recruitment program. Based on the donors' experiences with blood 
Table 5 Blood Shortage; Perspective of Healthcare Professionals $(n=372)$

\begin{tabular}{|c|c|c|}
\hline \multicolumn{2}{|l|}{ Blood Availability; Perspective of Healthcare Professionals } & \multirow{2}{*}{$\begin{array}{c}\begin{array}{c}\text { Number } \\
(\%)\end{array} \\
154(41.4) \\
218(58.6)\end{array}$} \\
\hline Do you experience any blood shortage during this pandemic? & $\begin{array}{l}\text { Yes } \\
\text { No }\end{array}$ & \\
\hline In your opinion, what is the main reason to shortage of blood in the current COVID-I9? & $\begin{array}{l}\text { Shortage of the donors } \\
\text { Increased blood demand } \\
\text { Shortage of blood bank staff } \\
\text { Shortage of reagents and blood bags } \\
\text { Other }\end{array}$ & $\begin{aligned} & 300(80.6) \\
& 28(7.5) \\
& 14(3.8) \\
& 10(2.7) \\
& 20(5.4)\end{aligned}$ \\
\hline In your opinion, what is the reason of donor's shortage? & $\begin{array}{l}\text { Fear of infection } \\
\text { Lockdown } \\
\text { Restriction of hospital entry } \\
\text { Other }\end{array}$ & $\begin{array}{c}300(80.6) \\
30(8.1) \\
16(4.3) \\
26(7)\end{array}$ \\
\hline In your opinion; how can we made the blood available for emergency needs? & $\begin{array}{l}\text { Initiate blood donation at home } \\
\text { Activate campaign } \\
\text { Announcement through social media } \\
\text { Other }\end{array}$ & $\begin{array}{l}136(36.6) \\
174(46.7) \\
22(5.9) \\
40(10.8)\end{array}$ \\
\hline In your opinion what is the suggested solution to overcome the blood shortage? & $\begin{array}{l}\text { Activation of the mobile drive blood } \\
\text { donation } \\
\text { Updating the criteria for blood release } \\
\text { Apply the patient blood management } \\
\text { Contact with the nearby blood banks } \\
\text { Others }\end{array}$ & $\begin{array}{l}282(75.8) \\
32(8.7) \\
18(4.8) \\
28(7.5) \\
12(3.2)\end{array}$ \\
\hline
\end{tabular}

donation, the majority $(69.4 \%)$ recommended mobile blood drives as the preferred place for donation during pandemics like the current situation. These results were in agreement with recent studies. ${ }^{26}$ This is possibly because blood donors were like to avoid visiting blood banks during the pandemic.

In this study, health care professionals were interviewed regarding their experience with blood supply and demand during the current COVID-19 pandemic. They indicated that they experienced blood shortage due to lack of donors $(80 \%)$. The main obstacle for blood donation was the fear of infection $(80.6 \%)$. These findings are consistent with the findings of previous studies that addressed blood needs and donation in this COVID-19 pandemic. The main solution suggested by the health professionals who participated in this study was to activate the mobile blood drive $(75.8 \%)$ at donors' homes, donors' workplaces, or educational institutions' residences after coordination with donors. This result is consistent with a recent report from Saudi Arabia Mobile blood drives are the most effective solution to the shortage associated with this pandemic due to the fear of infection in blood banks and difficult access to hospitals. ${ }^{9}$ Many institutions were faced with developing policies and procedures for blood management during the COVID-19 pandemic, particularly few first months of its occurrence. In such pandemic, it is essential to think deeply to find a solution for the blood shortage to maintain an optimal blood transfusion service. Decisionmakers can use the solutions suggested from participants for development and improvement of policy and regulations in health system. ${ }^{7,9,26}$

\section{Conclusions and Recommendations}

Blood donation is the backbone of blood supply. In emergencies blood donation, and management of the blood supply is challenging and fraught with obstacles for health system. The positive view of donors and health professionals reflected in this study will help design intervention programs to improve blood availability and solve blood shortages in emergencies such as the current COVID-1919 pandemic. Activating a mobile blood drive is strongly recommended to bridge the gap between blood supply and demand during a pandemic. 


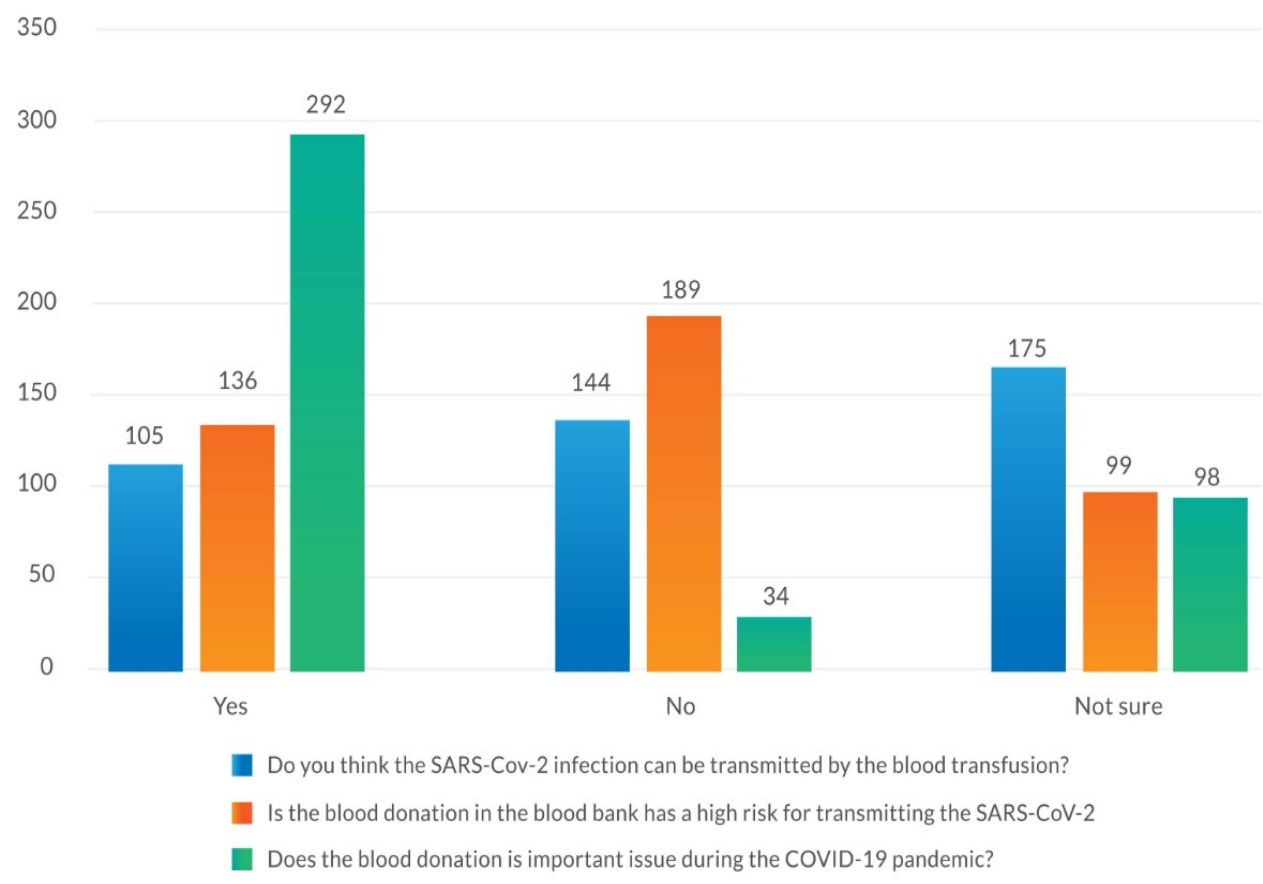

Figure I Perception of safety of blood donation; perspective of blood donors in KSA $(n=424)$.

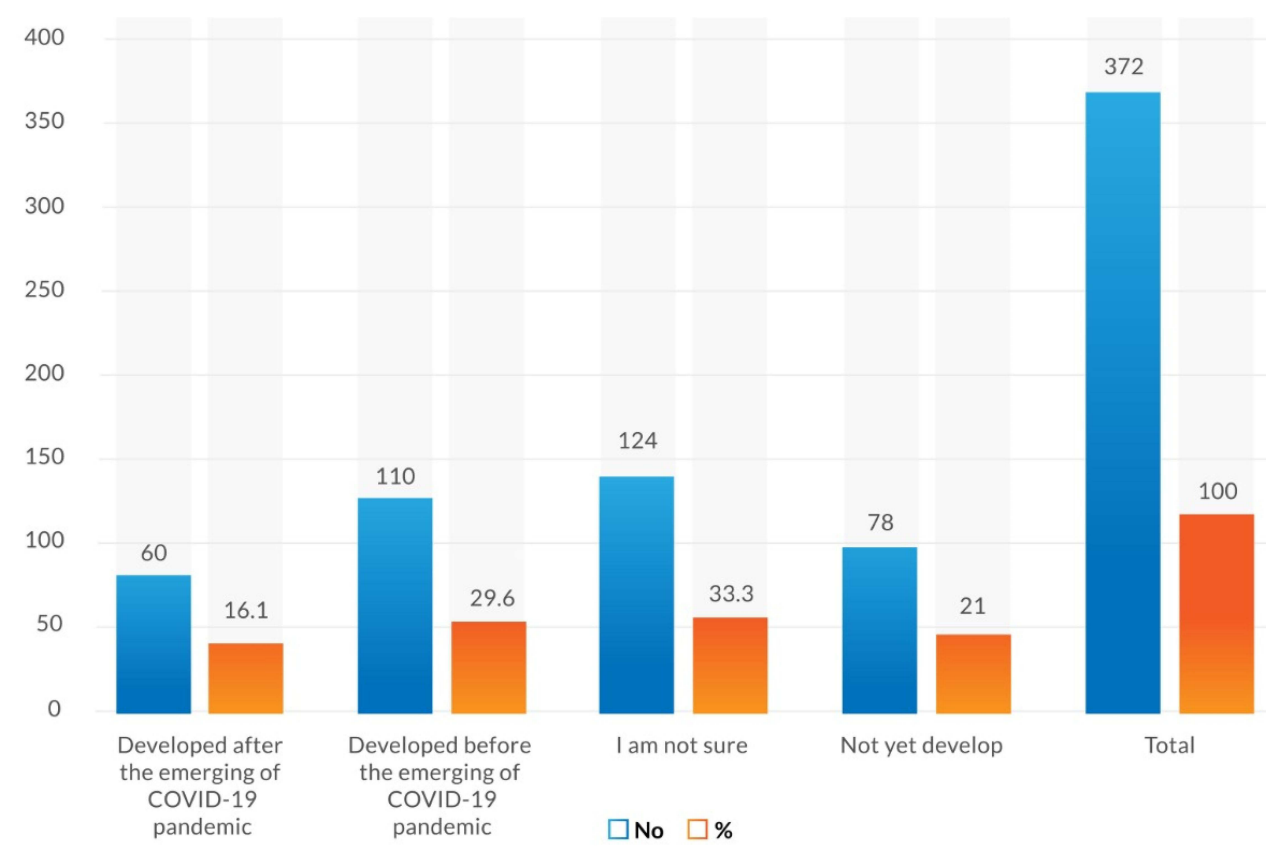

Figure 2 Development of the national strategy for blood supply and demand $(n=372)$.

\section{Abbreviations}

COVID-19, coronavirus disease; WHO, World Health Organization; SPSS, Statistical Package for Social Sciences.

\section{Ethics Approval and Consent}

This study was conducted in accordance with the Declaration of Helsinki. The institutional board review
(IRB) approval was obtained from King Abdallah Hospital-Bisha, Saudi Arabia. All participants gave informed consent before enrolling in the study.

\section{Acknowledgments}

The authors extended their appreciation to the deanship of Scientific Research at the University of Bisha Saudi 
Arabia for funding this work through COVID-19 Initiative Project under Grant Number (UB-COVID-06-1441).

\section{Author Contributions}

All authors made a significant contribution to the work reported, whether that is in the conception, study design, execution, acquisition of data, analysis and interpretation, or in all these areas; took part in drafting, revising or critically reviewing the article; gave final approval of the version to be published; have agreed on the journal to which the article has been submitted; and agree to be accountable for all aspects of the work.

\section{Disclosure}

The authors report no conflicts of interest in this work.

\section{References}

1. Al-Riyami AZ, Abdella YE, Badawi MA. The impact of COVID-19 pandemic on blood supplies and transfusion services in Eastern Mediterranean Region. Transfus Clinique et Biologique. 2021;28 (1):16-24. doi:10.1016/j.tracli.2020.11.002

2. Garcia-Lopez J, Delgadillo J, Vilarrodona A, et al.SARS-CoV-2/ COVID-19 pandemic: first wave, impact, response and lessons learnt in a fully integrated Regional Blood and Tissue Bank. Narrative Rep Blood Transfus. 2021;19(2):158. doi:10.2450/2021.0259-20

3. Stanworth SJ, New HV, Apelseth TO, et al.Effects of the COVID-19 pandemic on supply and use of blood for transfusion. Lancet Haematol. 2020. doi:10.1016/s2352-3026(20)30186-1

4. Wang Y, Han W, Pan L. Impact of COVID-19 on blood centres in Zhejiang province China. Vox Sang. 2020;115(6):502-506. doi:10.1111/vox.12931

5. Nieto-Calvache AJ, Quintero-Santacruz M, Macia-Mejía C, LópezGirón MC, Vergara-Galliadi LM, Ariza F. Dangerous shortage of blood banks as an indirect effect of SARS-CoV-2: an obstetrics perspective. Int J Gynecol Obstetr. 2020;151(3):424-430. doi:10.1002/ ijgo. 13409

6. Grandone E, Mastroianno M, Caroli A, Ostuni A. Blood supply and transfusion support in southern Italy: findings during the first four weeks of the SARS-CoV-2 pandemic. Blood Transfus. 2020;18 (3):230. doi:10.2450/2020.0107-20

7. Ngo A, Masel D, Cahill C, Blumberg N, Refaai MA. Blood banking and transfusion medicine challenges during the COVID-19 pandemic. Clin Lab Med. 2020;40(4):587-601. doi:10.1016/j.cll.2020.08.013

8. Abdel Gader AG, Al Gahtani F, Ramadan A, Osman AM, Farghali M, Al-Momen AK. Attitude to blood donation in Saudi Arabia. Asian J Transfus Sci. 2011;5(2):121. doi:10.4103/0973-6247.83235

9. Yahia AIO. Management of blood supply and demand during the COVID-19 pandemic in King Abdullah Hospital, Bisha, Saudi Arabia. Transfus Apheresis Sci. 2020;59(5):102836. doi:10.1016/j. transci.2020.102836
10. Nigam R, Pandya K, Luis AJ, Sengupta R, Kotha M. Positive effects of COVID-19 lockdown on air quality of industrial cities (Ankleshwar and Vapi) of Western India. Sci Rep. 2021;11(1):1-12. doi:10.1038/s41598-021-83393-9

11. Huo X, Sun X, Bragazzi N, Wu J. Effectiveness and feasibility of convalescent blood transfusion to reduce COVID-19 fatality ratio. Royal Soc Open Sci. 2021;8(2):202248. doi:10.2139/ssrn.3573611

12. Li Y, Liu S, Zhang S. Current treatment approaches for COVID-19 and the clinical value of transfusion-related technologies. Transfus Apheresis Sci. 2020;59(5):102839. doi:10.1016/j.transci.2020.102839

13. World Health Organization. Blood safety and availability fact sheet; 2020. Available from: https://www.who.int/news-room/fact-sheets /detail/blood-safety-and-availability. Accessed August 27, 2020.

14. Gammon RR, Rosenbaum L, Cooke R. Maintaining adequate donations and a sustainable blood supply: lessons learned. Transfusion. 2021;61(1):294-302. doi:10.1111/trf.16145

15. Chang L, Yan Y, Zhao L, et al.No evidence of SARS-CoV-2 RNA among blood donors: a multicenter study in Hubei, China. Transfusion. 2020;60(9):2038-2046. doi:10.1111/trf.15943

16. Gilchrist PT, Thijsen A, Masser BM, France CR, Davison TE. Improving the donation experience and reducing venipuncture pain by addressing fears among whole-blood and plasma donors. Transfusion. 2021. doi:10.1111/trf.16407

17. Rafiee MH, Kafiabad SA, Maghsudlu M. Analysis of blood donors' characteristics and deferrals related to COVID-19 in Iran. Transfus Apheresis Sci. 2021;60(2):103049. doi:10.1016/j.transci.2020.103049

18. Jain S, Garg K, Tran SM, et al.Characteristics of coronavirus disease 19 convalescent plasma donors and donations in the New York metropolitan area. Transfusion. 2021. doi:10.1111/trf.16421

19. Joyner MJ, Bruno KA, Klassen SA, et al. Safety update: COVID-19 convalescent plasma in 20,000 hospitalized patients. Mayo Clinic Proceedings. Elsevier; 2020:1888-1897. doi:10.1016/j.mayocp.20 20.06.028

20. Greffin K, Schmidt S, Schönborn L, Muehlan H. "Blood for blood"? Personal motives and deterrents for blood donation in the German population. Int $J$ Environ Res Public Health. 2021;18(8):4238. doi:10.3390/ijerph18084238

21. Hashemi S, Maghsudlu M, Nasizadeh S, Esmaielifar G, Pourfathollah AA. Effective ways to retain first-time blood donors: a field-trial study. Transfusion. 2019;59(9):2893-2898. doi:10.1111/ trf. 15404

22. Mugion RG, Pasca MG, Di Di Pietro L, Renzi MF. Promoting the propensity for blood donation through the understanding of its determinants. BMC Health Serv Res. 2021;21(1):1-20. doi:10.1186/ s12913-021-06134-8

23. Suen LKP, Siu JY-M, Lee YM, Chan EA. Knowledge level and motivation of Hong Kong young adults towards blood donation: a cross-sectional survey. BMJ Open. 2020;10(1):e031865. doi:10.1136/ bmjopen-2019-031865

24. Custer B, Johnson ES, Sullivan SD. Quantifying losses to the donated blood supply due to donor deferral and miscollection. Transfusion. 2004;44(10):1417-1426. doi:10.1111/j.1537-2995.2004.03374.x

25. Noordin SS, Yusoff NM, Karim FA, Chong SE. Blood transfusion services amidst the COVID-19 pandemic. J Glob Health. 2021;11. doi: $10.7189 /$ jogh.11.03053

26. Gottschall J, Wu Y, Triulzi D. The epidemiology of platelet transfusions: an analysis of platelet use at 12 US hospitals. Transfusion. 2020;60(1):46-53. doi:10.1111/trf.15637 


\section{Publish your work in this journal}

The Journal of Multidisciplinary Healthcare is an international, peerreviewed open-access journal that aims to represent and publish research in healthcare areas delivered by practitioners of different disciplines. This includes studies and reviews conducted by multidisciplinary teams as well as research which evaluates the results or conduct of such teams or healthcare processes in general. The journal

covers a very wide range of areas and welcomes submissions from practitioners at all levels, from all over the world. The manuscript management system is completely online and includes a very quick and fair peer-review system. Visit http://www.dovepress.com/testimonials. php to read real quotes from published authors. 